\title{
In Silico Molecular Studies of Antiophidic Properties of the Amazonian Tree Cordia nodosa Lam.
}

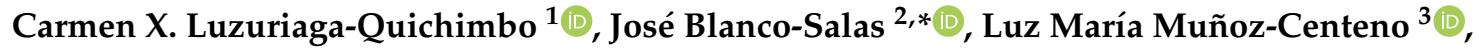 \\ Rafael Peláez ${ }^{4}\left(\mathbb{D}\right.$, Carlos E. Cerón-Martínez ${ }^{5}$ and Trinidad Ruiz-Téllez ${ }^{2}$ (D) \\ 1 Faculty of Health Sciences Eugenio Espejo, University UTE, Quito 170147, Ecuador; luzuriaga.cx@gmail.com \\ 2 Department, Faculty of Sciences, University of Extremadura, 06006 Badajoz, Spain; truiz@unex.es \\ 3 Department of Botany, University of Salamanca, 37008 Salamanca, Spain; luzma@usal.es \\ 4 Departament of Pharmaceutical Sciences, Organic Chemistry, University of Salamanca, 37008 Salamanca, \\ Spain; pelaez@usal.es \\ 5 Herbarioum Alfredo Paredes, QAP, Ecuador Central University UCE, Quito 170521, Ecuador; \\ carlosceron57@hotmail.com \\ * Correspondence: blanco_salas@unex.es; Tel.: +34-924-289-300
}

Academic Editor: Ericsson Coy-Barrera

Received: 11 October 2019; Accepted: 11 November 2019; Published: 16 November 2019

\begin{abstract}
We carried out surveys on the use of Cordia nodosa Lam. in the jungles of Bobonaza (Ecuador). We documented this knowledge to prevent its loss under the Framework of the Convention on Biological Diversity and the Nagoya Protocol. We conducted bibliographic research and identified quercetrin as a significant bioactive molecule. We studied its in silico biological activity. The selected methodology was virtual docking experiments with the proteins responsible for the venomous action of snakes. The molecular structures of quercetrin and 21 selected toxins underwent corresponding tests with SwissDock and Chimera software. The results point to support its antiophidic use. They show reasonable geometries and a binding free energy of -7 to $-10.03 \mathrm{kcal} / \mathrm{mol}$. The most favorable values were obtained for the venom of the Asian snake Naja atra $(5 \mathrm{Z} 2 \mathrm{G},-10.03 \mathrm{kcal} / \mathrm{mol})$. Good results were also obtained from the venom of the Latin American Bothrops pirajai ( $3 \mathrm{CYL},-9.71 \mathrm{kcal} / \mathrm{mol}$ ) and that of Ecuadorian Bothrops asper snakes (5TFV, $-9.47 \mathrm{kcal} / \mathrm{mol}$ ) and Bothrops atrox (5TS5, -9.49 $\mathrm{kcal} / \mathrm{mol}$ ). In the $5 \mathrm{Z} 2 \mathrm{G}$ and $5 \mathrm{TS} 5 \mathrm{~L}$-amino acid oxidases, quercetrin binds in a pocket adjacent to the FAD cofactor, while in the myotoxic homologues of PLA2, 3CYL and 5TFV, it joins in the hydrophobic channel formed when oligomerizing, in the first one similar to $\alpha$-tocopherol. This study presents a case demonstration of the potential of bioinformatic tools in the validation process of ethnobotanical phytopharmaceuticals and how in silico methods are becoming increasingly useful for sustainable drug discovery.
\end{abstract}

Keywords: Cordia; in silico; antiophidic; quercetrin; docking; validation

\section{Introduction}

Cordia is a tropical genus of arbustive Boraginaceae and is quite interesting from a pharmacological point of view [1]. More than thirty species are referenced as medicinal [2], having bioactive compounds such as rosmarinic acid, cordiaquinones and cordiachromes [3,4]. Cordia alliodora Cham., one of the most important timber trees in the Amazon, has an interesting chemical profile [5-11] with antimicrobial, antifungal, larvicidal [12] and cytotoxic activities [13] which have been experimentally tested. Cordia verbenaceae DC has been studied as anti-inflammatory [14], analgesic [15], antibacterial [16], antiallergic [17] and antitumoral [18]; the latter activity is attributed to the rosmarinic acid (Figure 1) [19]. 
<smiles>O=C(/C=C/c1ccc(O)c(O)c1)O[C@H](Cc1ccc(O)c(O)c1)C(=O)O</smiles>

Figure 1. Rosmarinic acid.

Another Cordia with promising properties is Cordia nodosa Lam, (= Cordia collococa Aubl [20]) a Pan-Amazonian species that contains [13] quercetrin (Figure 2), a strong antiproliferative in vitro.<smiles>C[C@H]1O[C@@H](Oc2c(-c3ccc(O)c(O)c3)oc3cc(O)cc(O)c3c2=O)[C@H](O)[C@H](O)[C@@H]1O</smiles>

Figure 2. Quercetrin.

In Amazonian Ecuador, many ethnic groups (cofan, redwood, siona, wao, shuar, achuar and kichwa) have reported references to the ancestral use [21]. The fruit is edible, the wood is employed for the construction of their houses in the jungle, and cultural ceremonies and rites are prepared with the leaves [21]. Cordia nodosa Lam contains phenols that justify its anti-inflammatory and analgesic applications and its moderate bactericidal action [22]. However, the most interesting ancestral knowledge of this plant is its ability to act as an antidote to snake bites [23]. This problem, seldom considered in Europe, affects millions of inhabitants of tropical areas of the planet and has not developed a pharmaceutical research according to its dimension [24]. Every year, about 5.4 million snake bites produce 1.8-2.7 million cases of poisoning, 81,410-137,880 deaths and about three times as many amputations and other permanent disabilities [24]. The World Health Organization has included snake bites in the category of "Neglected and Forgotten Diseases" [24].

In the context of ethnobotanical research conducted by our team in the Ecuadorian Amazon [21], we carried out surveys on the use of $C$. nodosa under the Framework of the Convention on Biological Diversity and the Nagoya Protocol [25]. We had two specific aims: (a) to describe the current use as an antivenom of $C$. nodosa in the Bobonaza Basin (Pastaza, Ecuador) and (b) to offer an in silico validation by searching the scientific literature and by overall performing docking tests.

\section{Results}

\subsection{Ethnobotanical Survey}

The medicinal uses given to the species retrieved from our fieldwork prospections and literature review are summarized in Table 1, which shows that the use of $C$. nodosa as an antiophidic is currently in force in indigenous Amazonian ethnic groups. Names like kuchamanku, awas, putunmuyu, machakuymisunsal or machakuykaspi have been published previously, but not paluwapu ("= snake 
stick"), which we learned from the canelo-kichwas cultures of Pastaza that we worked with [21]. We found that when a snake bite occurs, they take the bark, cook it for about one minute, and then drink the resulting liquid in a single dose.

Table 1. Medicinal uses given to the species retrieved from our fieldwork prospections and literature review.

\begin{tabular}{|c|c|c|c|c|c|}
\hline Organ/System & Part Used & Formulation & $\begin{array}{l}\text { Traditional } \\
\text { Knowledge }\end{array}$ & $\begin{array}{l}\text { Ethnic Group-Province } \\
\text { (Country) }\end{array}$ & Reference \\
\hline $\begin{array}{l}\text { Circulatory } \\
\text { system }\end{array}$ & leaves & decoction & hypertension & $\begin{array}{l}\text { Amerindian NorthWest } \\
\text { District (Guiana) }\end{array}$ & {$[26]$} \\
\hline $\begin{array}{l}\text { Digestive } \\
\text { system }\end{array}$ & & & gases & Siona-Sucumbíos (Ecuador) & {$[23]$} \\
\hline \multirow{5}{*}{$\begin{array}{l}\text { Respiratory } \\
\text { system }\end{array}$} & bark & \multirow{2}{*}{ cooking } & \multirow{2}{*}{ treat cough } & \multirow{2}{*}{ Secoya-Sucumbíos (Ecuador) } & \multirow{2}{*}{ [23] } \\
\hline & stem & & & & \\
\hline & inner bark & $\begin{array}{l}\text { finely grate and } \\
\text { decoction }\end{array}$ & $\begin{array}{l}\text { cold and shortness of } \\
\text { breath }\end{array}$ & Amerindian (French Guiana) & {$[26]$} \\
\hline & leaves & decoction & whooping cough & $\begin{array}{l}\text { Amerindian NorthWest } \\
\text { District (Guiana) }\end{array}$ & {$[26]$} \\
\hline & fruit & suck & snot in babies & $\begin{array}{l}\text { Amerindian NorthWest } \\
\text { District (Guiana) }\end{array}$ & {$[26]$} \\
\hline $\begin{array}{l}\text { Musculature } \\
\text { and skeleton }\end{array}$ & leaves & $\begin{array}{l}\text { crush the leaves and rub } \\
\text { the body with them }\end{array}$ & $\begin{array}{l}\text { rheumatism, sprains, } \\
\text { muscle aches, bruises }\end{array}$ & $\begin{array}{l}\text { Amerindian NorthWest } \\
\text { District (Guiana) }\end{array}$ & {$[26]$} \\
\hline \multirow{2}{*}{$\begin{array}{l}\text { Nervous } \\
\text { system and } \\
\text { mental illness }\end{array}$} & \multirow[t]{2}{*}{ leaves } & $\begin{array}{c}\text { baths with the decoction } \\
\text { of the leaves }\end{array}$ & $\begin{array}{c}\text { madness and } \\
\text { psychiatric disorders }\end{array}$ & Yanesha (Perú) & {$[27]$} \\
\hline & & decoction & headache & $\begin{array}{c}\text { Amerindian NorthWest } \\
\text { District (Guiana) }\end{array}$ & [26] \\
\hline \multirow{5}{*}{$\begin{array}{l}\text { Symptoms and } \\
\text { states of } \\
\text { undefined } \\
\text { origin }\end{array}$} & bark & & \multirow{2}{*}{$\begin{array}{l}\text { indeterminate } \\
\text { conditions }\end{array}$} & Secoya-Sucumbíos (Ecuador) & \multirow{4}{*}{ [23] } \\
\hline & flowers & & & $\begin{array}{l}\text { Kichwa del Oriente-Orellana } \\
\text { (Ecuador) }\end{array}$ & \\
\hline & fruit & & energizing & Wao-Orellana (Ecuador) & \\
\hline & \multirow[t]{2}{*}{ leaves } & infusion & dizziness & $\begin{array}{l}\text { ethnicity not specified-Napo } \\
\text { (Ecuador) }\end{array}$ & \\
\hline & & decoction & fever & $\begin{array}{l}\text { Amerindian NorthWest } \\
\text { District (Guiana) }\end{array}$ & {$[26]$} \\
\hline \multirow{12}{*}{ Poisoning } & leaves & $\begin{array}{l}\text { apply directly in the } \\
\text { affected place }\end{array}$ & \multirow{5}{*}{$\begin{array}{l}\text { spider bite, to decrease } \\
\text { inflammation and } \\
\text { prevent gangrene }\end{array}$} & \multirow{5}{*}{$\begin{array}{l}\text { East Kichwa-Napo and } \\
\text { Orellana (Ecuador) }\end{array}$} & \multirow{5}{*}[23]{} \\
\hline & fruit & & & & \\
\hline & plant & cooking & & & \\
\hline & bark & cooking & & & \\
\hline & root & cooking & & & \\
\hline & \multirow{2}{*}{ bark } & scraped and in water & \multirow{7}{*}{$\begin{array}{l}\text { snake bites, to decrease } \\
\text { inflammation and } \\
\text { prevent gangrene }\end{array}$} & \multirow{7}{*}{$\begin{array}{l}\text { East Kichwa, Shuar-Napo, } \\
\text { Orellana, Pastaza, Sucumbíos } \\
\text { (Ecuador), Piaroa (Venezuela) }\end{array}$} & \multirow{7}{*}[23,26]{} \\
\hline & & infusion & & & \\
\hline & root & infusion & & & \\
\hline & stem & juice & & & \\
\hline & fruit & juice & & & \\
\hline & young leaves & chewed & & & \\
\hline & leaves & $\begin{array}{l}\text { apply directly in the } \\
\text { affected place }\end{array}$ & & & \\
\hline
\end{tabular}

\subsection{Chemical and Activity Prospection: Results of the Bibliographic Review}

The main component of the extract was quercetrin, a $3 \alpha$-L-rhamnoside of quercetin. The genine has a chemical structure based on a C6-C3-C6 carbon skeleton, with a chromene ring bearing a second aromatic ring at position 2. Therefore, it is a flavonoid, specifically a flavonol (Figure 2). This is a chemical group in which antiophidic properties are known [28]. 
The literature review performed is summarized in the following tables. It is known that snake venom comprises peptides and proteins that act as cytotoxins, neurotoxins, hemotoxins or myotoxins. The 21 molecular targets of snakebite poisonings, retrieved from our bibliographic research, are shown in Table 2.

Table 2. Toxins from Ecuadorian (1-2), Latin American (3-13) or non-American (14-21) snakes, and the corresponding Protein Data Base Identifier (PDB ID).

\begin{tabular}{|c|c|c|}
\hline Toxin & PDB ID & Reference \\
\hline 1. MT-I-Basic phospholipase a2 myotoxin iii & 5TFV & [29] \\
\hline 2. LAAO_L-amino acid oxidase from Bothrops atrox & 5TS5 & [30] \\
\hline 3. PLA2-Phospholipase A2: Piratoxin I (myotoxic Lys49-PLA2) from Bothrops pirajai & $3 C Y L$ & [31] \\
\hline 4. PLA2-Phospholipase A2: BthTX-I-Bothropstoxin I from Bothrops jararacussu venom/ & 3CXI & [31] \\
\hline 5. PLA2-Phospholipase A2: Myotoxin (MjTX-I) from Bothrops moojeni & 6CE2 & [32] \\
\hline 6. PLA2-Phospholipase A2: Bothropstoxin I (BthTX-I) & $6 \mathrm{DIK}$ & [33] \\
\hline 7. svPLA2-Phospholipase A2: myotoxin II from Bothrops moojeni & $1 \mathrm{XXS}$ & [34] \\
\hline 8. LAAO-L-amino acid oxidasefrom the B. jararacussu venom & $4 \mathrm{E} 0 \mathrm{~V}$ & [35] \\
\hline 9. svPLA2-Acidic phospholipase A2 (BthA-I) from Bothrops jararacussu & $1 Z 76$ & [36] \\
\hline 10. VRV-PL-V-Crotoxin B, the basic PLA2 from Crotalus durissusterrificus & 2QOG & [37] \\
\hline 11. PLA2-Piratoxin-II (Prtx-II) - a K49 PLA2 from Bothrops pirajai & $1 Q L L$ & [38] \\
\hline 12. Bothropasin, the Main Hemorrhagic Factor from Bothrops jararaca venom & 3DSL & [39] \\
\hline 13. SVMP-P-I snake venom metalloproteinase BaP1 & $2 \mathrm{~W} 12$ & {$[40]$} \\
\hline 14. NNH1-L-amino acid oxidase from venom of Naja atra & $5 Z 2 G$ & [41] \\
\hline 15. LAAO_L-amino acid oxidase from Vipera ammodytes venom & $3 \mathrm{KVE}$ & [42] \\
\hline 16. PDE I-Phosphodiesterase (PDE) from Taiwan cobra (Naja atra atra) venom & $5 \mathrm{GZ4}$ & [43] \\
\hline 17. VRV-PL-V-Phospholipase ACII4 from Australian King Brown Snake (Pseudechis australis) & $3 \mathrm{~V} 9 \mathrm{M}$ & {$[44]$} \\
\hline 18. NN-PL-I-Phospholipase A2 from indian cobra (Naja naja) & 1PSH & [45] \\
\hline 19. LAAO_L-amino acid oxidase from Agkistrodon Halys Pallas (Gloydius halys) & $1 \mathrm{REO}$ & [46] \\
\hline 20. NNH1-Phosphodiesterase (PDE) fromTaiwan cobra (Naja atra atra) & $5 \mathrm{GZ5}$ & {$[47]$} \\
\hline 21. PLA2-Phospholipase A2 (Pla2) from Naja naja & $1 \mathrm{~A} 3 \mathrm{D}$ & {$[48,49]$} \\
\hline
\end{tabular}

\subsection{Docking}

The liaison energies of quercetrin with the studied targets are presented in Table 3. They have been colored by groups according to their similarity to the rest of the sequences (see Supplementary Material for details). They oscillate between $-10.03 \mathrm{kcal} / \mathrm{mol}$ and $-7.01 \mathrm{kcal} / \mathrm{mol}$.

Table 3. The liaison energies of quercetrin with the PDB ID studied targets.

\begin{tabular}{rrrr}
\hline 1. & 5TFV & -9.71 & MT-I-Basic Phospholipase a2 Myotoxin iii \\
2. & 5TS5 & -9.47 & LAAO-L-amino acid oxidase from Bothrops atrox \\
3. & 3CYL & -9.49 & PLA2-Phospholipase A2: Piratoxin I (myotoxic Lys49-PLA2) from Bothrops pirajai \\
4. & 3CXI & -9.37 & PLA2-Phospholipase A2: BthTX-I-Bothropstoxin I from Bothrops jararacussu venom/ \\
5. & 4GUE & -9.30 & N-terminal kinase domain of RSK2 with flavonoid glycoside quercetrin \\
6. & 6CE2 & -9.19 & PLA2-Phospholipase A2: Myotoxin (MjTX-I) from Bothrops moojeni \\
7. & 6DIK & -9.16 & PLA2-Phospholipase A2: Bothropstoxin I (BthTX-I) \\
8. & 1XXS & -9.01 & sVPL2-Phospholipase A2: myotoxin II from Bothrops moojeni \\
9. & 4E0V & -8.96 & LAAO-L-amino acid oxidasefrom the B. jararacussu venom \\
10. & 1Z76 & -8.56 & sVPLA2-Acidic phospholipase A2 (BthA-I) from Bothrops jararacussu \\
11. & 2QOG & -8.32 & VRV-PL-V-Crotoxin B, the basic PLA2 from Crotalus durissusterrificus \\
12. & 5A4W & -8.28 & AtGSTF2 from Arabidopsis thaliana \\
13. & 1QLL & -8.23 & PLA2-Piratoxin-II (Prtx-II) - a K49 PLA2 from Bothrops pirajai \\
14. & 3DSL & -8.20 & Bothropasin, the Main Hemorrhagic Factor from Bothrops jararaca venom. \\
15. & 2W12 & -7.71 & SVMP-P-I snake venom metalloproteinase BaP1
\end{tabular}

Figures 3-15 show the molecular models of the quercetrin binding with the targets of Table 3 (left) and the corresponding 2D interaction diagram generated with LigPlot + (right) [50], made with UCSF Chimera Software. Toxins are represented in golden yellow, quercetrin in blue, and original ligands in pink. The small squares (a) show the toxin-quercetrin complex in the most favorable arrangement. When it occupies the hollow of another ligand present in the structure of the target, it has been preserved (shown as thin sticks in pink) to allow a comparison. The augmented figures (b) show, in detail, the dispositions of the quercetrin molecule between the chains of the toxins. 

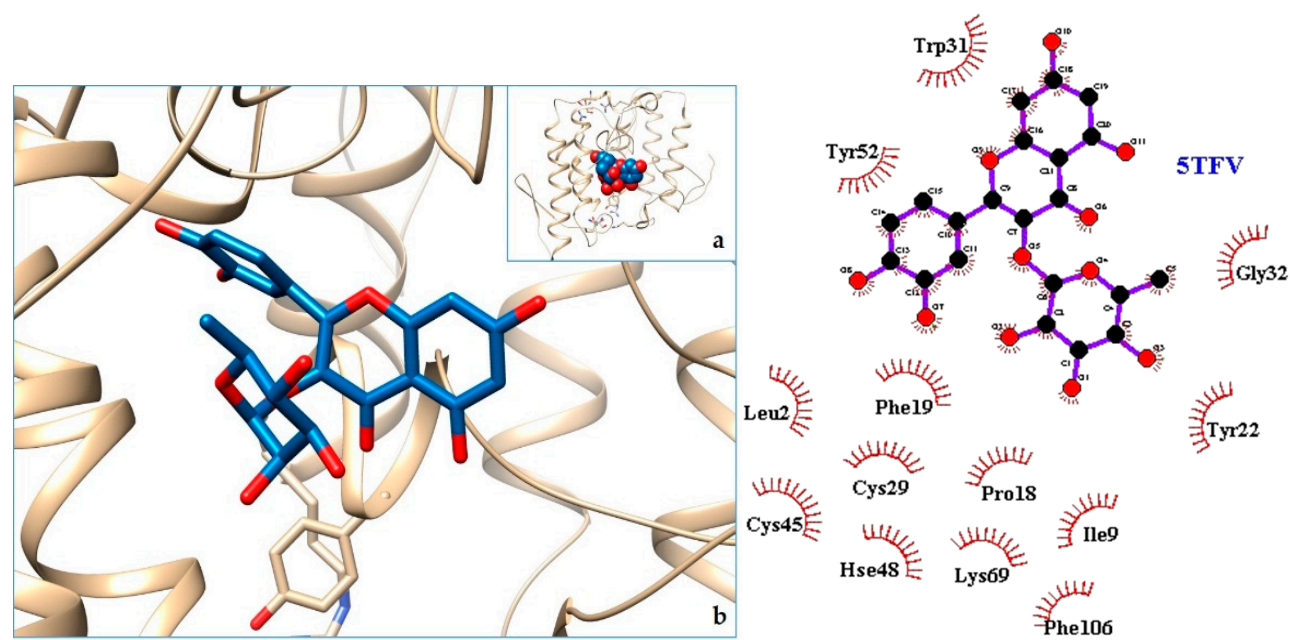

Figure 3. 5TFV-quercetrin complex. in the most favourable arrangement (a) and augmented (b) showing the disposition between the chain of toxins. Right: 2D interaction diagram.

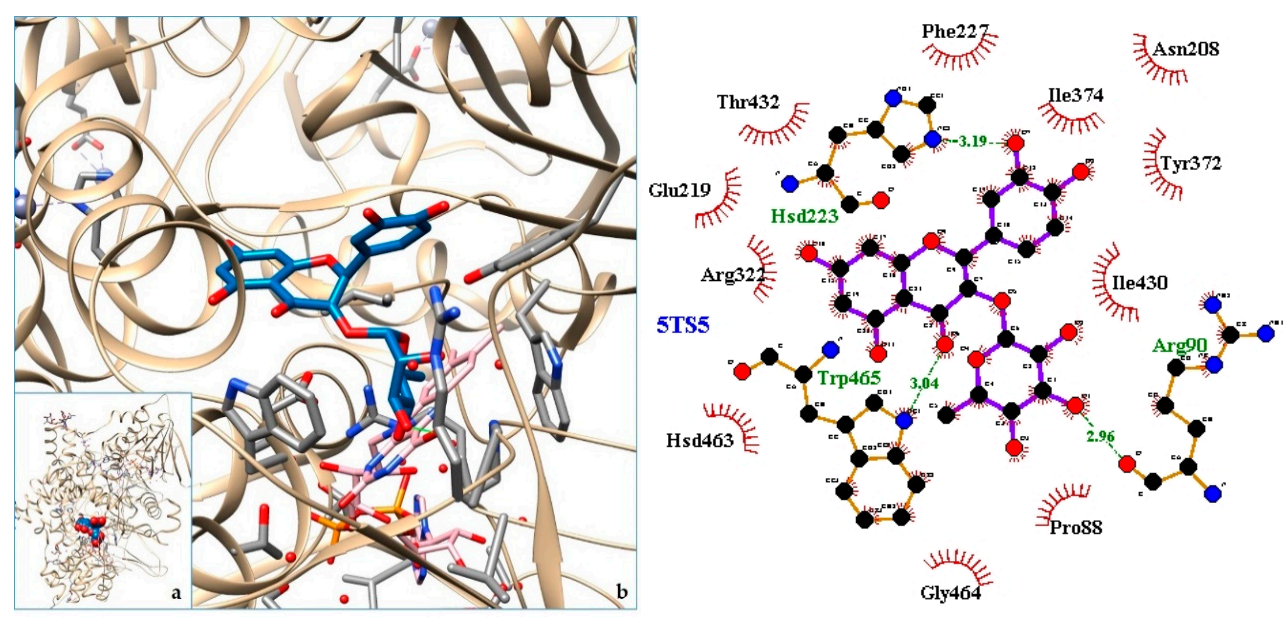

Figure 4. 5TS5-quercetrin complex. in the most favourable arrangement (a) and augmented (b) showing the disposition between the chain of toxins. Right: 2D interaction diagram.
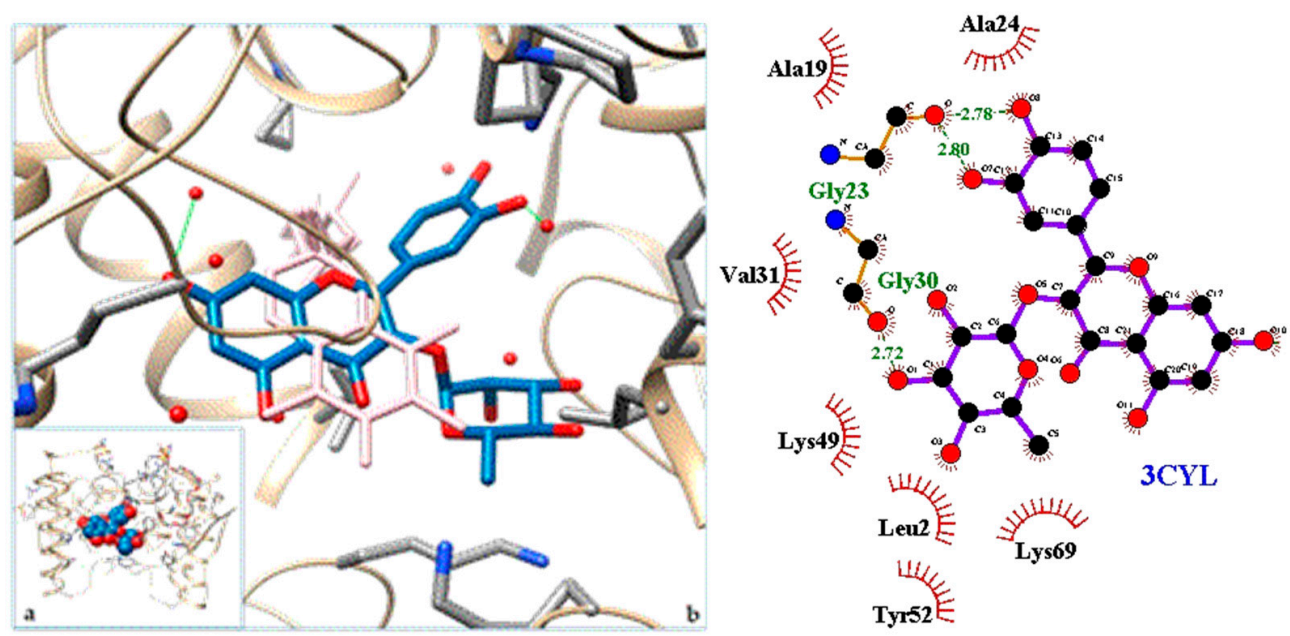

Figure 5. 3CYL quercetrin complex in the most favourable arrangement (a) and augmented (b) showing the disposition between the chain of toxins. Right: 2D interaction diagram. 


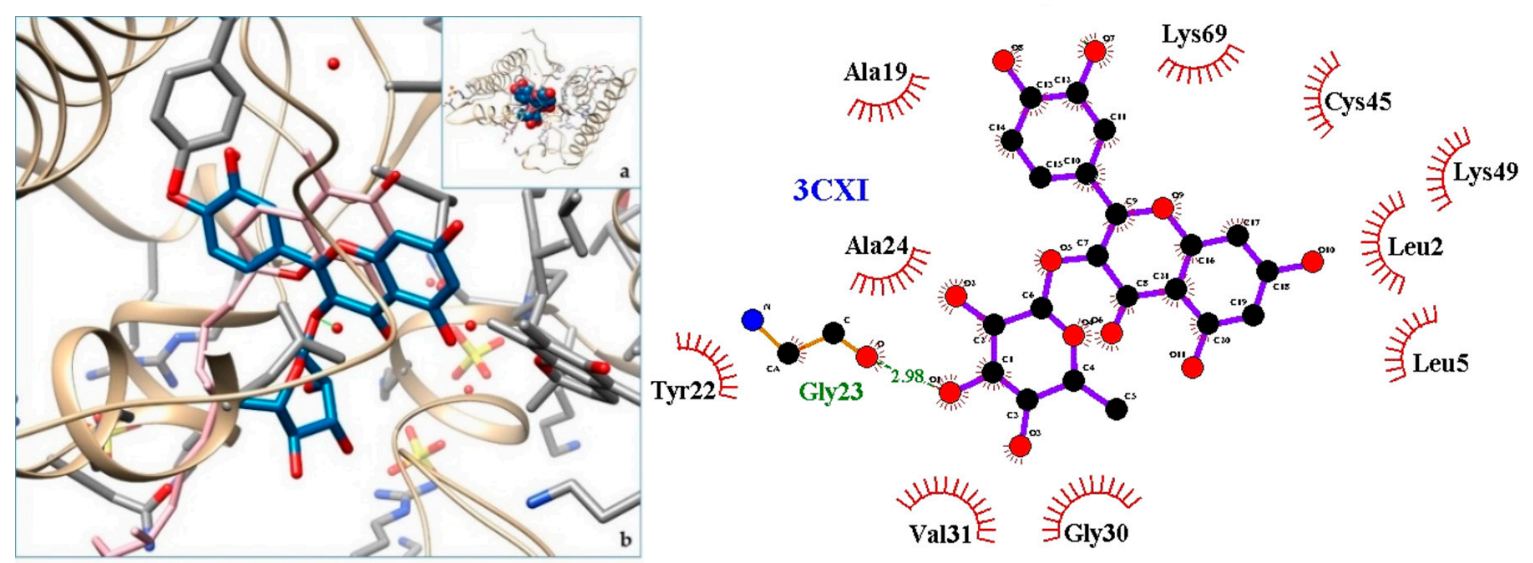

Figure 6. 3CXI-quercetrin complex in the most favourable arrangement (a) and augmented (b) showing the disposition between the chain of toxins. Right: 2D interaction diagram.
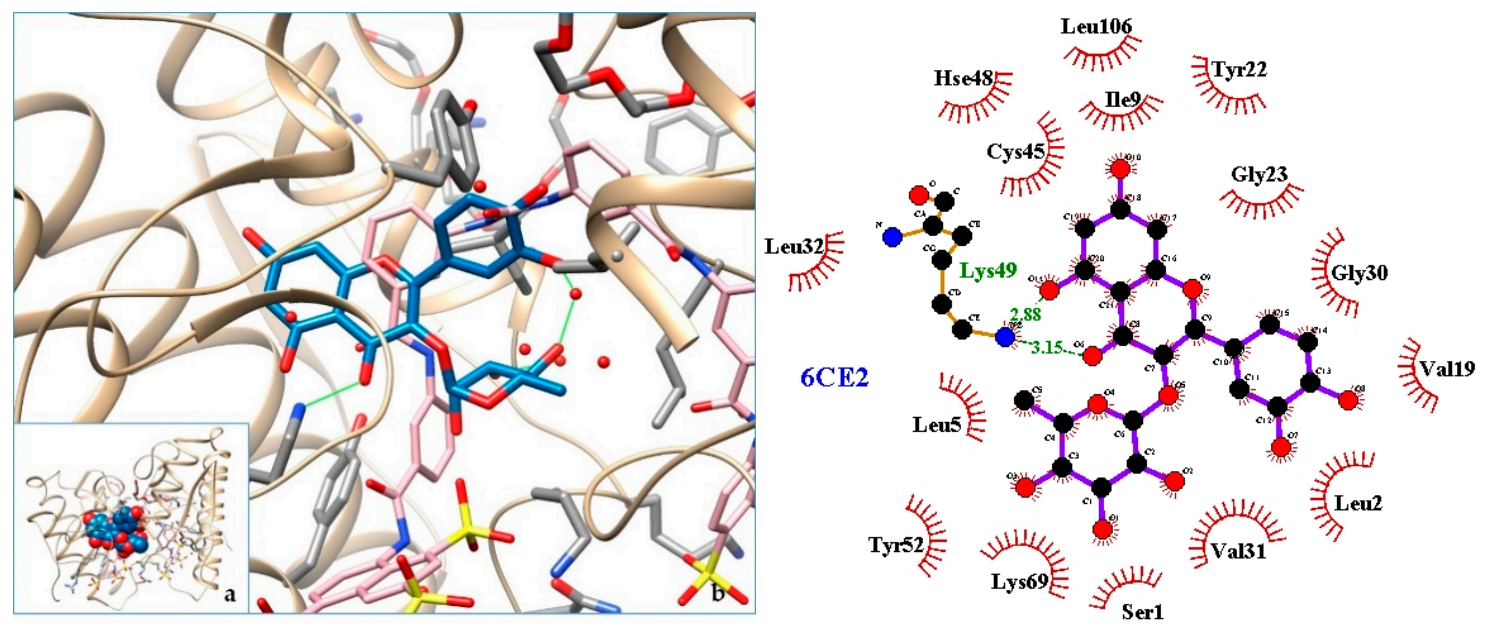

Figure 7. 6CE2-q uercetrin complex in the most favourable arrangement (a) and augmented (b) showing the disposition between the chain of toxins. Right: 2D interaction diagram.
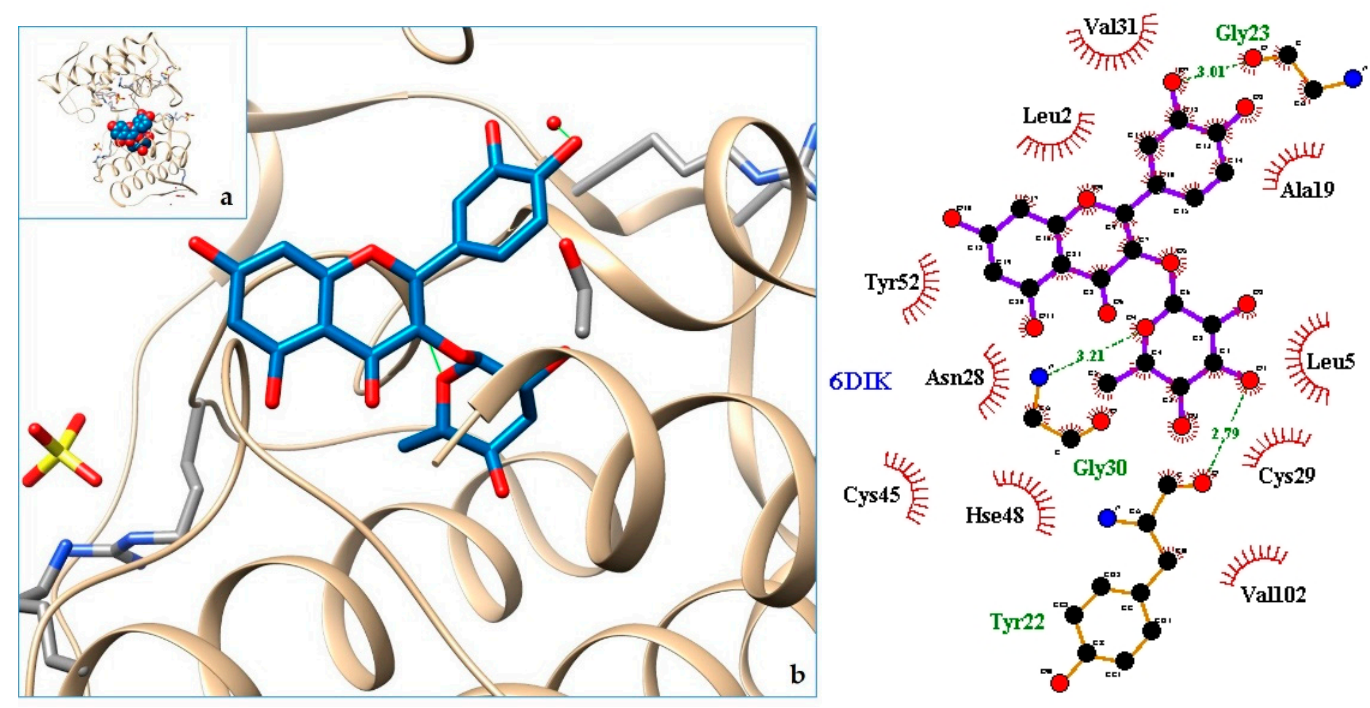

Figure 8. 6DIK-quercetrin complex in the most favourable arrangement (a) and augmented (b) showing the disposition between the chain of toxins. Right: 2D interaction diagram. 


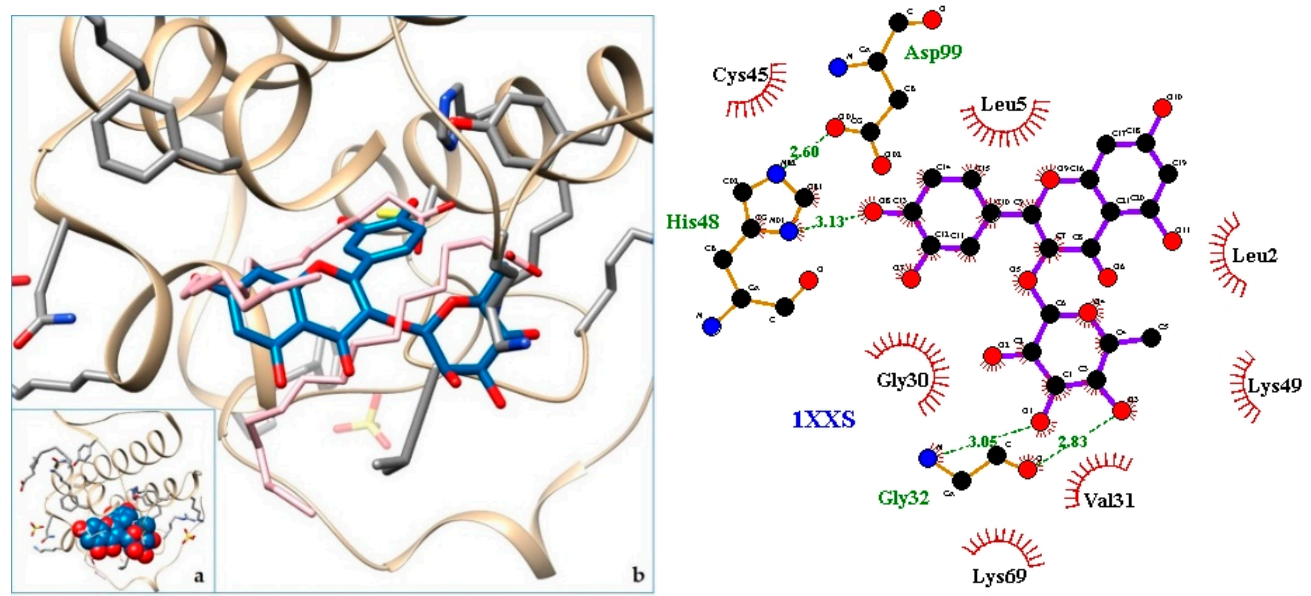

Figure 9. 1XXS-quercetrin complex in the most favourable arrangement (a) and augmented (b) showing the disposition between the chain of toxins. Right: 2D interaction diagram.

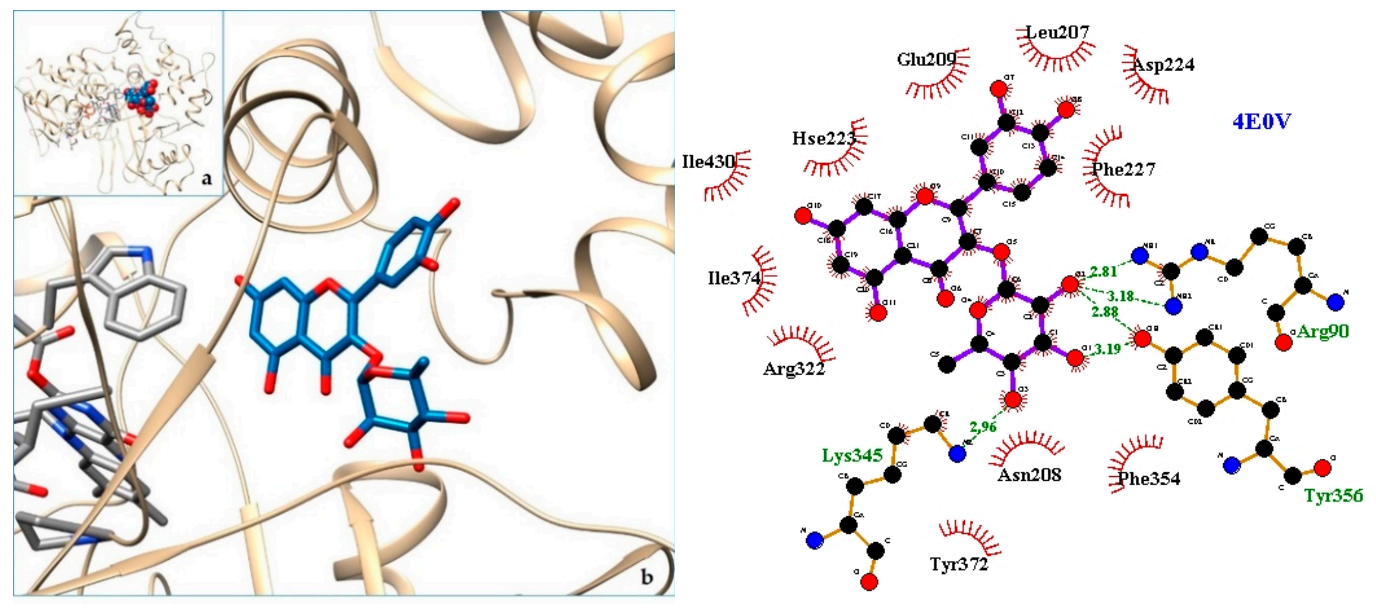

Figure 10. 4E0V-quercetrin complex in the most favourable arrangement (a) and augmented (b) showing the disposition between the chain of toxins. Right: 2D interaction diagram.
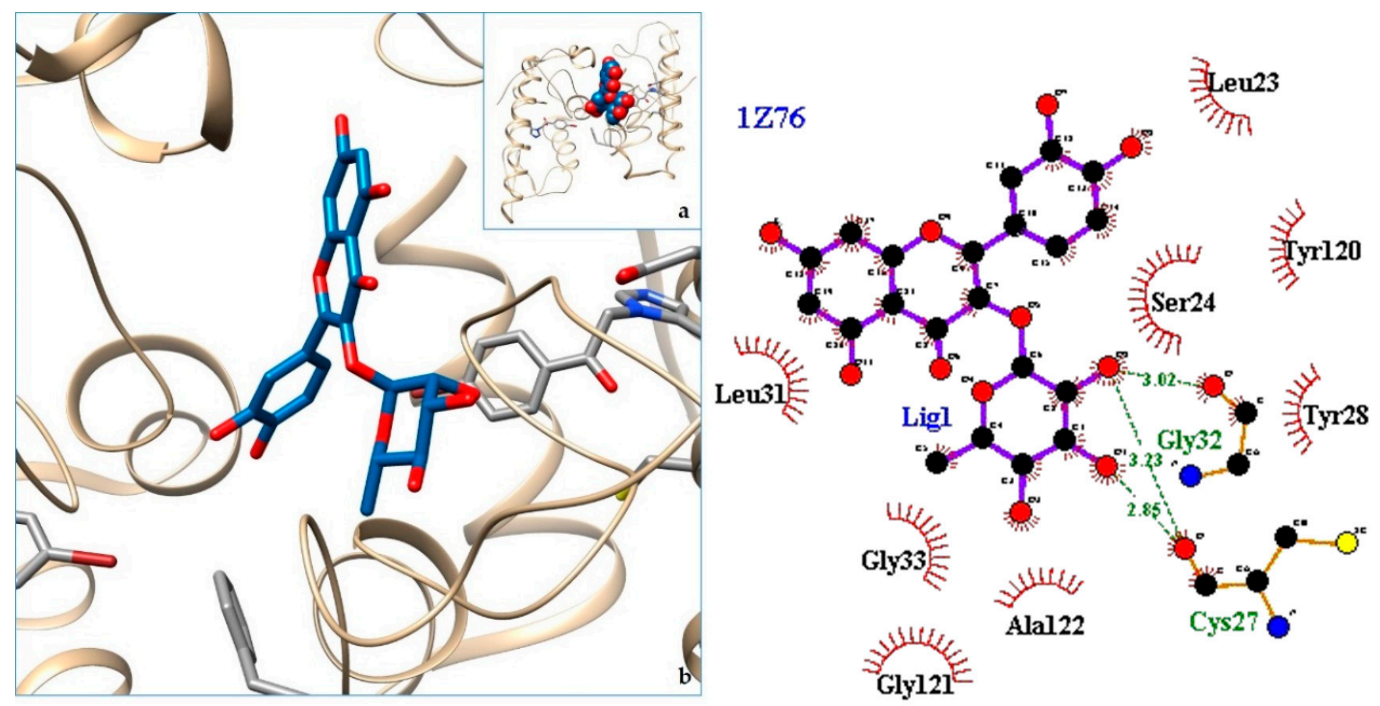

Figure 11. 1Z76-quercetrin complex in the most favourable arrangement (a) and augmented (b) showing the disposition between the chain of toxins. Right: 2D interaction diagram. 

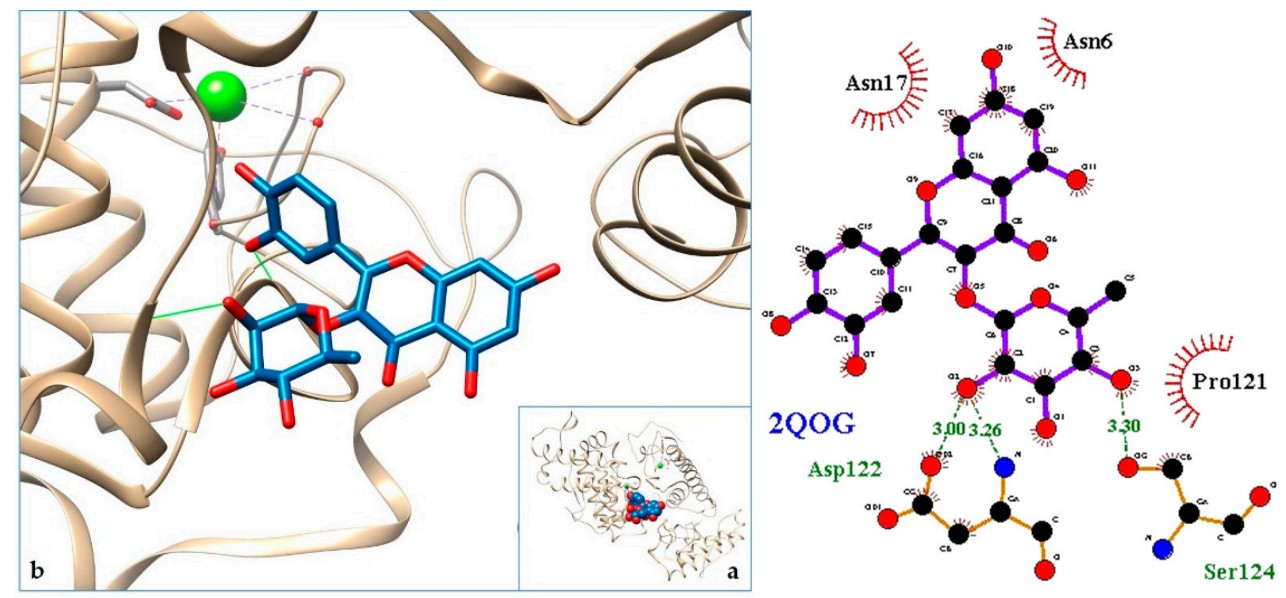

Figure 12. 2QOG-quercetrin complex in the most favourable arrangement (a) and augmented (b) showing the disposition between the chain of toxins. Right: 2D interaction diagram.
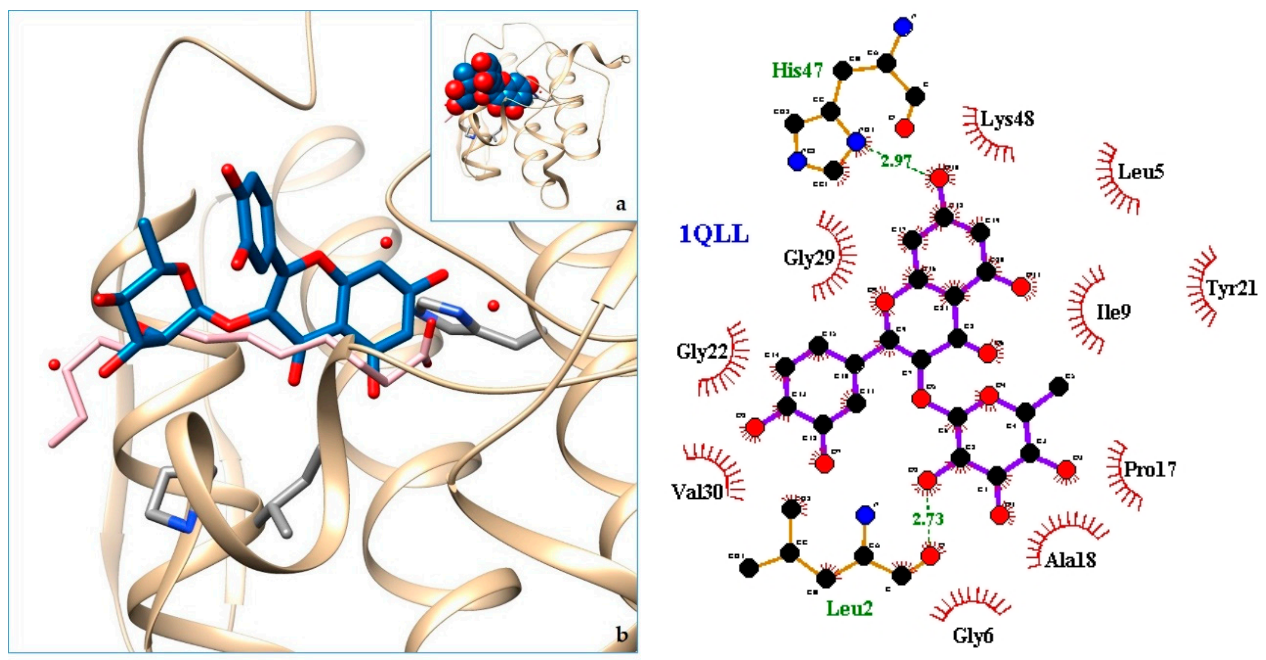

Figure 13. 1QLL-quercetrin complex in the most favourable arrangement (a) and augmented (b) showing the disposition between the chain of toxins. Right: 2D interaction diagram.
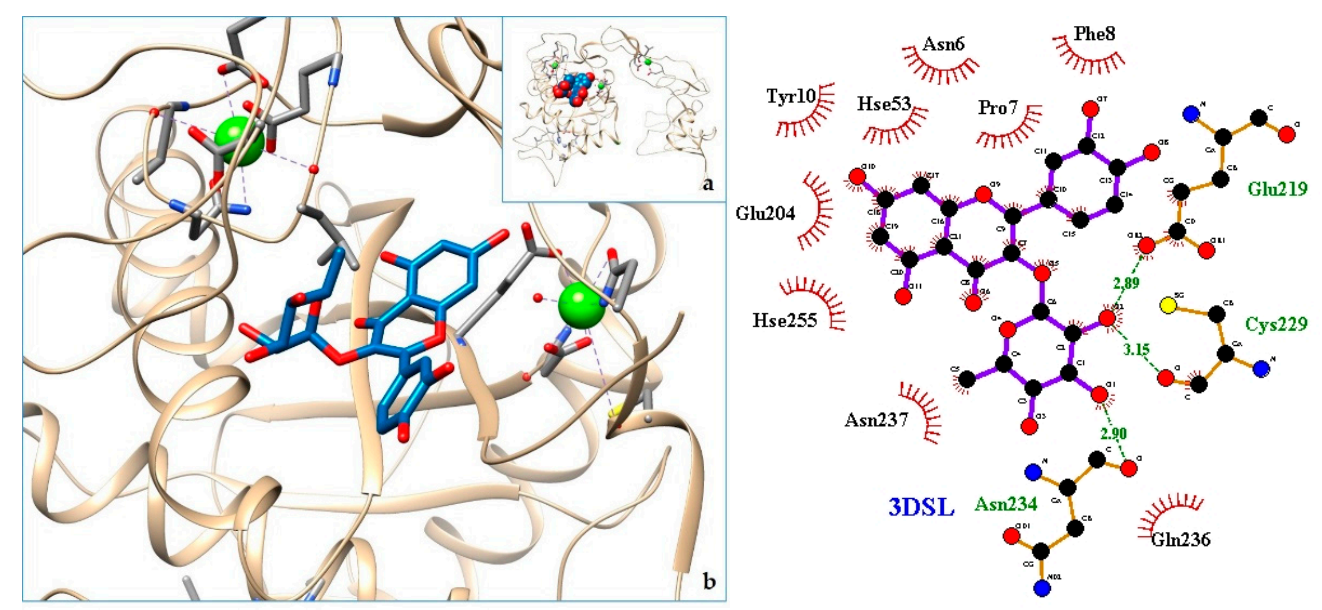

Figure 14. 3DSL-quercetrin complex in the most favourable arrangement (a) and augmented (b) showing the disposition between the chain of toxins. Right: 2D interaction diagram. 


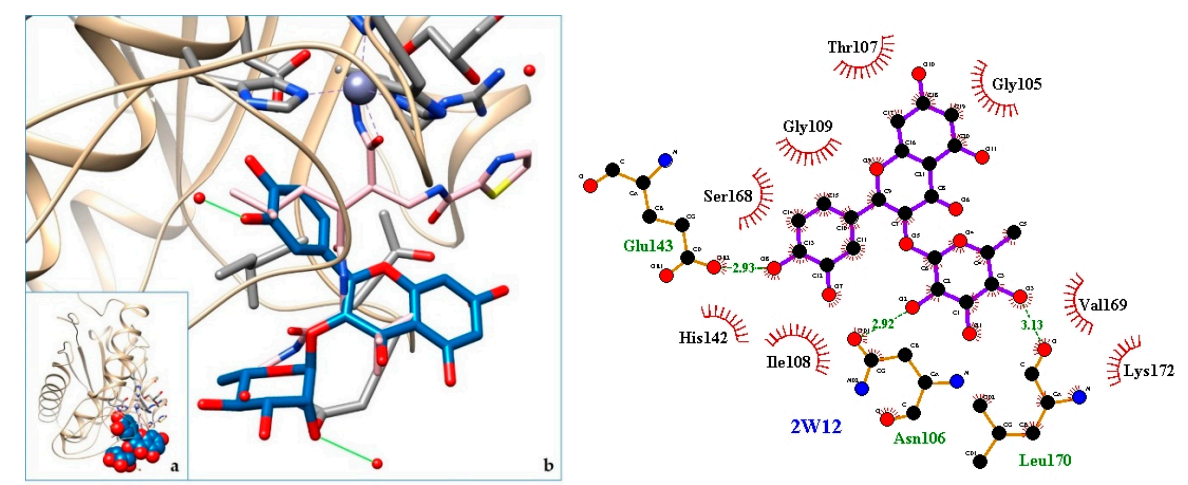

Figure 15. 2W12-quercetrin complex in the most favourable arrangement (a) and augmented (b) showing the disposition between the chain of toxins. Right: 2D interaction diagram.

\section{Discussion}

The traditional use of this plant for its antiophidic properties has been previously documented by the Shuar and the Napo-Rune people of neighboring provinces, although the method of application is different. In these cases, the plant is applied directly to the affected place, or they chew the young leaves and the fruits. They also prepare infusions, not with the bark, but with the root or the juice of the stem [23]. Published references on the activity of quercetrin have indicated that it inhibits lipoxygenase svPLA2 [51] and hyaluronidase NNH1 [52], neutralizing the hemorrhagic venom of Bothrops jararaca [51-53], a Latin American snake.

In the docking tests that we carried out, the toxic snakes studied showed very high affinities with quercetrin. There were formed complexes of energy comparable to the ones with original targets such as $4 \mathrm{GEW}$ or $5 \mathrm{~A} 4 \mathrm{~W}$. Detailed information about these protein homologies has been included in Appendix A (Table A1). Thus, reasonable binding free energy values of -7 to $-10 \mathrm{kcal} / \mathrm{mol}$ were obtained. The most favorable values were for the venom of the Asian snake (Chinese cobra or Taiwan cobra) Naja atra $(5 \mathrm{Z} 2 \mathrm{G},-10.03 \mathrm{kcal} / \mathrm{mol})$ and the Latin American Bothrops pirajai (3CYL, $-9.71 \mathrm{kcal} / \mathrm{mol})$. Very good results were also found with the $5 \mathrm{TFV}$ of the Ecuadorian snakes Bothrops asper, $(\Delta \mathrm{G}-9.47 \mathrm{kcal} / \mathrm{mol})$ and 5 TS5 of Bothrops atrox ( $\Delta \mathrm{G}-9.49 \mathrm{kcal} / \mathrm{mol})$. Therefore, quercetrin can not only be used as an antiophid for Ecuadorian venomous snakes, but for many others.

The action can be expected to be effective, especially because, in addition, the models have not presented unfavorable interactions according to SwissDock scoring terms. On many occasions, the quercetrin molecule is placed in pockets that occupy other known ligands of the targets used in this study. This is the case for 3CYL and 3CXI (Figures $5 \mathrm{~b}$ and $6 \mathrm{~b}$ ), which occupy the pocket of $\alpha$-tocopherol, 5TS5 (Figure 4b), which is close to that of FAD, 6CE2 (Figure 7b), that occupies that of suramin (a known inhibitor), 1XXS (Figure 9b), that of two stearic acids, 1QLL (Figure 13b), that of tridecanoic acid, and 2W12 (Figure 15b), which occupies the peptidomimetic inhibitor site. All of this reinforces the validity of the results of the performed docking tests.

In the 5Z2G and 5TS5 L-amino acid oxidases, quercetrin binds in a pocket adjacent to the FAD cofactor, while in the myotoxic homologues of PLA2, 3CYL and 5TFV, it joins in the hydrophobic channel formed when oligomerizing in the first one, similar to $\alpha$-tocopherol.

These facts reinforce the validity of the traditional use reported. They will have to be corroborated in vitro, in vivo, and even with subsequent clinical trials. Nevertheless, this is encouraging evidence in the field of finding new solutions to this pathology.

\section{Materials and Methods}

\subsection{Ethnobotanical Survey}

All the information referring to the ethnobotanical study from which the data derives is available in Appendix A, which contains references to voucher specimens, authorizations and permissions. 
Table 1 summarizes the medicinal uses of the species retrieved from our fieldwork prospections and literature data.

\subsection{Chemical and Activity Prospection: Bibliographic Review}

A bibliographic review was carried out following the PRISMA Group method [54]. The databases accessed were Academic Search Complete, Agricola, Agris, Biosis, CABS, Cochrane, Cybertesis, Dialnet, Directory of Open Access Journals, Embase, Espacenet, Google Patents, Google Academics, Medline, PubMed, Science Direct, Scopus, Teseo, and ISI Web of Science. The selected citations were summarized, and a critical reading allowed us to develop the discussion.

\subsection{Docking}

The molecular docking method applied comprises the following procedures: ligand preparation, protein selection, docking, and analysis of the results. The energies produced after docking, interaction residues and interaction types were studied for the analyses following general procedure for molecular docking $[55,56]$. Docking was performed with the SwissDock Docking Web Service (Available online: http://www.loc.gov). A 3D quercetrin virtual structure was built with Spartan ${ }^{\circledR}$, Wavefunction Inc. Selection of targets was made based on a bibliographic review of natural bioactive compounds against snake bites [28,54]. A total of 21 venoms from snakes (targets) with known X-ray structures were tested (see Table 2, Table 3 and Supplementary Material). Molecular structures were consulted in the Protein Data Bank (PDB), and the reference IDs were taken to include them in the Swiss Dock Program. The target + ligand set was considered stable when the values of the binding free energy were lower than -7 $\mathrm{kcal} / \mathrm{mol}$. This consideration is based on docking experiments with the known X-ray structures 4GUE and $5 \mathrm{~A} 4 \mathrm{~W}$ complexes of quercetrin resulting in binding energies values of -9.30 and $-8.28 \mathrm{kcal} / \mathrm{mol}$, respectively. Once the results of the docking were obtained, they were analyzed with UCSF Chimera.

\section{Conclusions}

The information obtained from the ethnobotanical investigations carried out in the Bobonaza Basin (Ecuador) allowed us to verify the good capacity in silico of quercetrin, the active ingredient obtained from Cordia nodosa. The binding energies of quercetrin with all the macromolecules (toxins from venoms of different snakes) were adequate, since they were all less than $-7 \mathrm{kcal} / \mathrm{mol}$.

The in silico docking evaluation combined with ethnobotanical information was very effective as a research method. It allowed us to select the appropriate active principle from the beginning, thus avoiding the tedious previous work of testing principle assets that have no references and therefore working blindly with molecules that would not couple to these toxins. The search for new bio-products oriented from basic ethnobotanical knowledge is an investigation that could result in products with great therapeutic efficacies.

Supplementary Materials: The following are available online at http://www.mdpi.com/1420-3049/24/22/4160/s1, Table S1: Similarity matrix for the target proteins. Table S2: Heat map of sequence similarities as indicated in Table S1.

Author Contributions: Conceptualization T.R.-T. methodology, C.E.C.-M. and C.X.L.-Q.; validation J.B.-S.; formal analysis, R.P. and L.M.M.-C.; investigation, C.X.L.-Q.; data curation, C.E.C.-M. and C.X.L.-Q.; writing-original draft preparation, T.R.-T.; writing-review and editing, J.B.-S., R.P. and L.M.M.-C.; visualization, L.M.M.-C. and R.P.; supervision, C.X.L.-Q.; project administration, T.R.-T.; funding acquisition, C.X.L.-Q., J.B.-S. and T.R.-T.

Funding: This research was partially funded by the Government of Extremadura (Spain) and the European Union through the action "Apoyos a los Planes de Actuación de los Grupos de Investigación Catalogados de la Junta de Extremadura: FEDER GR18169.

Acknowledgments: We are grateful to the members of the Kichwa community of Pakayaku, Ms. Luzmila Gayas, the People's Assembly of Pakayaku and the collaborating ayllus (families), for their cooperation during the field work. F. Centeno Velázquez, D. Morales Jadan (University of Extremadura), collaborated actively in the improvement of the original manuscript. 
Conflicts of Interest: The authors declare no conflict of interest. The founding sponsors had no role in the design of the study; in the collection, analyses, or interpretation of data; in the writing of the manuscript, and in the decision to publish the results.

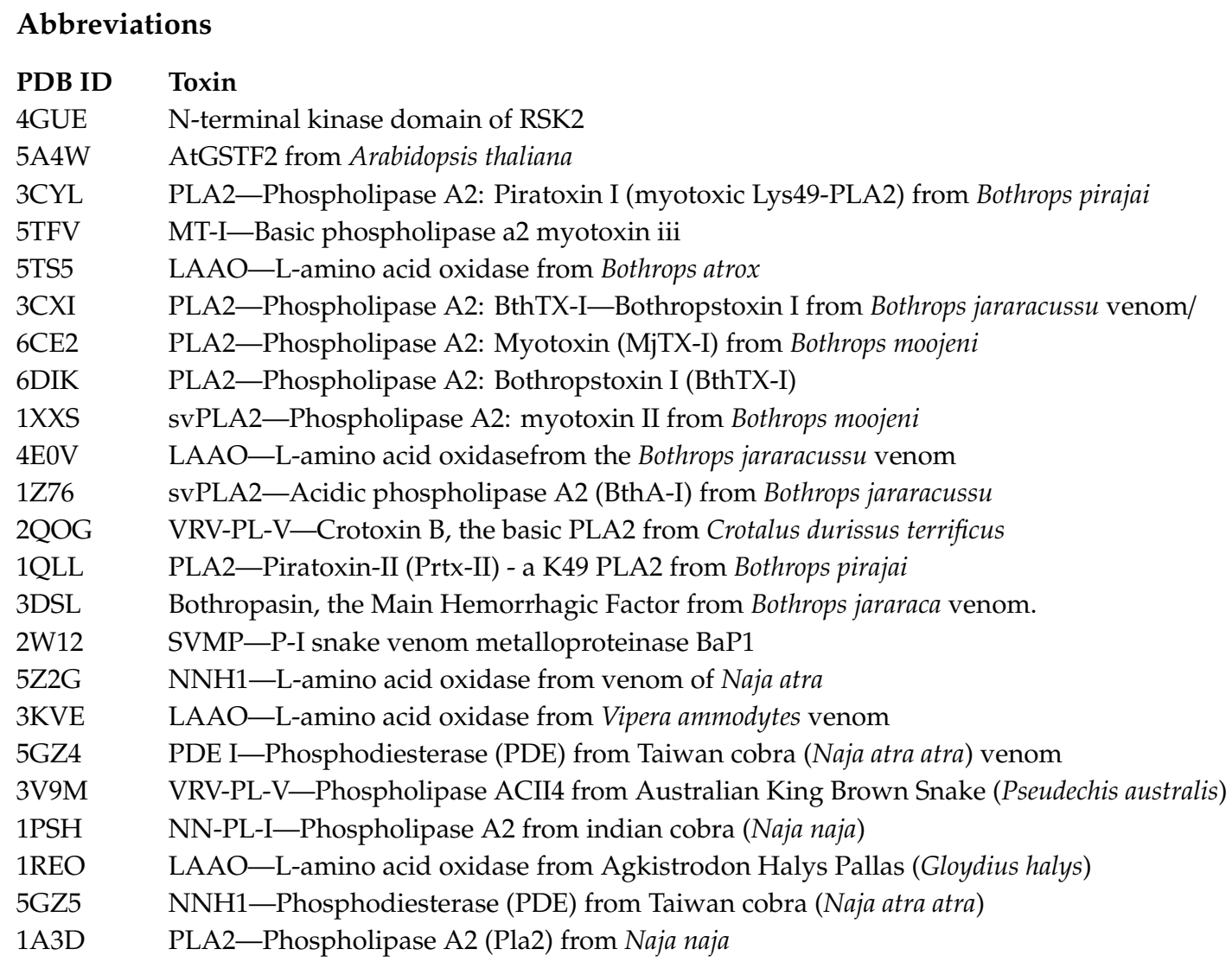

\section{Appendix A}

The Kichwa community of Pakayaku (Bobonaza River, Pastaza, Ecuador) lies in a fairly isolated region where bio- and ethno-diversity studies are still lacking. One of us (CXLQ) was based in the Biological Station PindoMirador in the northern Bobonaza River basin ( $\left.\mathrm{S}^{\circ} 27^{\prime} 09^{\prime \prime}-\mathrm{W} 78^{\circ} 04^{\prime} 51^{\prime \prime}\right)$, and since 2008 was in charge of environmental monitoring and education programs involving the local population.

Permissions and Authorizations/Ethnobotanical Survey: Under the Protocole of Nagoye (CBD, 2010) collective written research consent was granted by Mrs. Luzmila Gayas, the community president of the Assembly of Pakayaku. Permissions for collecting and moving plant material (MAE-DPAP-2016-2243) was granted by the Ministry of Environment of Ecuador. Prior verbal individual consents were obtained from the persons taking part in our survey. Our investigation consisted of a series of planned residential visits and treks accompanied by Kichwa interpreters and the local inhabitants of Pakayaku.

Vouchers: Sheets at Herbarium Alberto José Paredes, Universidad Central de Ecuador, Quito (QAP). Ecuador, Pastaza: Pakayaku, banks of the Bobonaza River, sector of Yanalpa, chacra $\mathrm{n}^{\circ} 6$ belonging to Mr. Aparicio Aranda, two hours walking away from the community, $592 \mathrm{~m}, 01^{\circ} 39^{\prime} 03^{\prime \prime} \mathrm{S}, 077^{\circ} 34^{\prime} 36^{\prime \prime} \mathrm{W}$, lowland evergreen forest, 23 January 2016, C. X. Luzuriaga-Q $\mathcal{E}$ R. Aranda (QAP 92888); sector of Aychatambo, banks of the Bobonaza River, upstream by canoe, twenty minutes away from the community, $425 \mathrm{~m}, 01^{\circ} 37^{\prime} 51.8^{\prime \prime} \mathrm{S}, 077^{\circ} 36^{\prime} 31.4^{\prime \prime} \mathrm{W}$, lowland evergreen forest, 27 November 2015, C. X. Luzuriaga-Q \& L. Gayas (QAP 92547). Material identified by C. Cerón Martínez.

Interviews: They were semi-structured and included a series of open questions aimed to encourage discussion. Knowledgeable elders of the Pakayaku community acted as informants and agreed to reveal their knowledge on the species and to be recorded. The informants answered freely on several topics, including the common name of Kichwa, part of the plant used, description of usage, harvest season, storage (if any), preparation of concoction, and the target of the treatment.

Informatization: After the fieldwork, the data were included into an MS Excel spreadsheet. All the uses recorded were classified according to the classification scheme proposed by [21], which is in turn based on the report of De la Torre and coworkers [23]. Cordia nodosa data are included in Table 1. 
Table A1. Similarity matrix for the target proteins. In each cell the upper number represents the percentage of identity and the lower the percentage of similarity for the protein in that row. The number in parenthesis represent the corresponding amino-acid number after Smith-Waterman comparison of the sequences. The cells are colored according to the percentage of similarity: $<25 \%$ yellow, $25-50 \%$ orange, $50-75 \%$ green and $>75 \%$ light blue. Diagonal cells with $100 \%$ identity are colored in dark blue. The protein IDs in the upper row have been colored by groups according to their similarity to the rest of the sequences.

\begin{tabular}{|c|c|c|c|c|c|c|c|c|c|c|c|c|c|c|c|}
\hline & $\begin{array}{l}\text { 4GUE } \\
(305)\end{array}$ & $\begin{array}{c}\text { AA4W } \\
(212)\end{array}$ & $\begin{array}{c}\text { 1QLL } \\
(121)\end{array}$ & $\begin{array}{l}\text { 1XXS } \\
(122) \\
\end{array}$ & $\begin{array}{l}1 Z 76 \\
(123) \\
\end{array}$ & $\begin{array}{c}2 \mathrm{QOG} \\
(122)\end{array}$ & $\begin{array}{l}2 \mathrm{~W} 12 \\
(202)\end{array}$ & $\begin{array}{l}3 C X I \\
(121) \\
\end{array}$ & $\begin{array}{l}3 \text { CYL } \\
(121)\end{array}$ & $(419)$ & $\begin{array}{l}\text { 4E0V } \\
(497) \\
\end{array}$ & $\begin{array}{l}\text { TTFV } \\
(122) \\
\end{array}$ & $\begin{array}{l}\text { 5TS5 } \\
(484) \\
\end{array}$ & $\begin{array}{l}6 \text { CE2 } \\
(121)\end{array}$ & $\begin{array}{l}\text { 6DIK } \\
(121) \\
\end{array}$ \\
\hline $\begin{array}{l}4 \mathrm{GUE} \\
(305)\end{array}$ & $100 \%$ & $\begin{array}{r}2.95 \%(9) \\
5.25 \%(16)\end{array}$ & $\begin{array}{l}1.64 \%(5) \\
2.30 \%(7)\end{array}$ & $\begin{array}{l}1.64 \%(5) \\
2.95 \%(9)\end{array}$ & $\begin{array}{l}1.97 \%(6) \\
1.97 \%(6)\end{array}$ & $\begin{array}{l}1.31 \%(4) \\
1.31 \%(4)\end{array}$ & $\begin{array}{r}8.20 \%(25) \\
14.10 \%(43)\end{array}$ & $\begin{array}{l}1.97 \%(6) \\
2.95 \%(9)\end{array}$ & $\begin{array}{l}1.64 \%(5) \\
2.30 \%(7)\end{array}$ & $\begin{array}{l}5.90 \%(18) \\
8.20 \%(25)\end{array}$ & $\begin{array}{c}8.52 \%(26) \\
16.07 \%(49)\end{array}$ & $\begin{array}{c}1.97 \%(6) \\
3.28 \%(10)\end{array}$ & $\begin{array}{r}6.23 \%(19) \\
13.77 \%(42)\end{array}$ & $\begin{array}{l}1.31 \%(4) \\
1.64 \%(5)\end{array}$ & $\begin{array}{l}1.97 \%(6) \\
2.95 \%(9)\end{array}$ \\
\hline $\begin{array}{c}5 \mathrm{~A} 4 \mathrm{~W} \\
(212)\end{array}$ & $\begin{array}{r}4.25 \% \text { (9) } \\
755 \%\end{array}$ & 100 & $2.36 \%(5)$ & $2.83 \%(6)$ & $2.83 \%(6)$ & $3.77 \%(8)$ & $6.60 \%(14)$ & $2.36 \%(5)$ & $2.62 \%(13)$ & $4.25 \%(9)$ & $19.81 \%(42)$ & $2.36 \%(5)$ & $19.81 \%(42)$ & $5.19 \%(11)$ & $2.36 \%(5)$ \\
\hline $\begin{array}{l}\text { (212) } \\
\text { 1QLL }\end{array}$ & $\frac{7.55 \%(16)}{4.13 \%(5)}$ & $4.13 \%(5)$ & $2.83 \%(6)$ & $\begin{array}{c}4.72 \%(10) \\
93.39 \%(113)\end{array}$ & $\begin{array}{c}4.25 \%(9) \\
48.76 \%(59)\end{array}$ & $\begin{array}{c}4.25 \%(9) \\
48.76 \%(59)\end{array}$ & $\begin{array}{c}\frac{9.91 \%(21)}{4.96 \%(6)} \\
\text { (6) }\end{array}$ & $\begin{array}{c}2.83 \%(6) \\
98.35 \%(119)\end{array}$ & $\begin{array}{c}3.43 \%(17) \\
99.17 \%(120)\end{array}$ & $\begin{array}{l}8.49 \%(18) \\
14.05 \%(17)\end{array}$ & $\begin{array}{l}35.38 \%(75) \\
19.83 \%(24)\end{array}$ & $\frac{2.83 \%(6)}{60.33 \%(73)}$ & $\begin{array}{c}35.38 \%(75) \\
5.79 \%(7)\end{array}$ & $\begin{array}{c}6.60 \%(14) \\
86.78 \%(105)\end{array}$ & $\begin{array}{l}2.83 \%(6) \\
99.17 \%(120)\end{array}$ \\
\hline (121) & $5.79 \%$ (7) & $4.96 \%(6)$ & $100 \%$ & $95.04 \%(115)$ & $70.25 \%(85)$ & $62.81 \%(76)$ & $7.44 \%(9)$ & $99.17 \%(120)$ & $99.17 \%(120)$ & $21.49 \%(26)$ & $35.54 \%(43)$ & $71.07 \%(86)$ & $9.09 \%(11)$ & $89.26 \%(108)$ & $99.17 \%(120)$ \\
\hline $\begin{array}{l}1 X X S \\
(122)\end{array}$ & $\begin{array}{l}4.10 \%(5) \\
7.38 \%(9)\end{array}$ & $\begin{array}{l}4.92 \%(6) \\
8.20 \%(10)\end{array}$ & $\begin{array}{c}92.62 \% \\
\text { (113) } 94.26 \% \\
\text { (115) }\end{array}$ & $100 \%$ & $\begin{array}{l}50.82 \%(62) \\
69.67 \%(85)\end{array}$ & $\begin{array}{l}49.18 \%(60) \\
63.11 \%(77)\end{array}$ & $\begin{array}{l}4.92 \%(6) \\
7.38 \%(9)\end{array}$ & $\begin{array}{l}94.26 \%(115) \\
95.08 \%(116)\end{array}$ & $\begin{array}{l}92.62 \%(113) \\
94.26 \%(115)\end{array}$ & $\begin{array}{l}13.93 \%(17) \\
21.31 \%(26)\end{array}$ & $\begin{array}{r}9.84 \%(12) \\
16.39 \%(20)\end{array}$ & $\begin{array}{l}59.84 \%(73) \\
69.67 \%(85)\end{array}$ & $\begin{array}{l}4.10 \%(5) \\
5.74 \%(7)\end{array}$ & $\begin{array}{l}82.79 \%(101) \\
85.25 \%(104)\end{array}$ & $\begin{array}{l}93.44 \%(114) \\
95.08 \%(116)\end{array}$ \\
\hline $\begin{array}{l}1776 \\
(122)\end{array}$ & $\begin{array}{l}4.92 \%(6) \\
4.92 \%(6)\end{array}$ & $\begin{array}{l}4.92 \%(6) \\
7.38 \%(9)\end{array}$ & $\begin{array}{l}48.36 \%(59) \\
69.67 \%(85)\end{array}$ & $\begin{array}{l}50.82 \%(62) \\
69.67 \%(85)\end{array}$ & $100 \%$ & $\begin{array}{l}56.56 \%(69) \\
66.39 \%(81)\end{array}$ & $\begin{array}{l}7.38 \%(9) \\
9.02 \%(11)\end{array}$ & $\begin{array}{c}50.0 \%(61) \\
70.49 \%(86)\end{array}$ & $\begin{array}{l}48.36 \%(59) \\
69.67 \%(85)\end{array}$ & $\begin{array}{l}18.85 \%(23) \\
28.69 \%(35)\end{array}$ & $\begin{array}{l}8.20 \%(19) \\
9.02 \%(11)\end{array}$ & $\begin{array}{l}56.56 \%(69) \\
71.31 \%(87)\end{array}$ & $\begin{array}{l}8.20 \%(10) \\
9.84 \%(12)\end{array}$ & $\begin{array}{l}50.00 \%(61) \\
65.57 \%(80)\end{array}$ & $\begin{array}{l}49.18 \%(60) \\
70.49 \%(86)\end{array}$ \\
\hline $\begin{array}{l}2 \mathrm{QOG} \\
(122)\end{array}$ & $\begin{array}{l}3.28 \%(4) \\
3.28 \%(4)\end{array}$ & $\begin{array}{l}6.56 \%(8) \\
7.38 \%(9)\end{array}$ & $\begin{array}{c}48.36 \% \\
\text { (59) } 62.30 \% \\
(76) \\
\end{array}$ & $\begin{array}{l}49.18 \%(60) \\
63.11 \%(77)\end{array}$ & $\begin{array}{l}56.56 \%(69) \\
66.39 \%(81)\end{array}$ & $100 \%$ & $10.66 \%(13)$ & $\begin{array}{l}47.54 \%(58) \\
62.30 \%(76)\end{array}$ & $\begin{array}{l}48.36 \%(59) \\
62.30 \%(76)\end{array}$ & $\begin{array}{l}22.13 \%(27) \\
28.69 \%(35)\end{array}$ & $\begin{array}{r}9.84 \%(12) \\
18.03 \%(22)\end{array}$ & $\begin{array}{l}63.93 \%(78) \\
76.23 \%(93)\end{array}$ & $\begin{array}{r}9.84 \%(12) \\
18.03 \%(22)\end{array}$ & $\begin{array}{l}47.54 \%(58) \\
57.38 \%(70)\end{array}$ & $\begin{array}{l}48.36 \%(59) \\
62.30 \%(76)\end{array}$ \\
\hline $\begin{array}{l}2 \mathrm{~W} 12 \\
(202)\end{array}$ & $\begin{array}{l}12.38 \%(25) \\
21.29 \%(43)\end{array}$ & $\begin{array}{l}6.93 \%(14) \\
10.40 \%(21)\end{array}$ & & & & & $100 \%$ & $\begin{array}{c}2.97 \%(6) \\
4.46 \%(9) 9\end{array}$ & $\begin{array}{l}2.97 \%(6) \\
4.46 \%(9)\end{array}$ & $\begin{array}{c}52.48 \% \\
(106) \\
67.82 \% \\
(137)\end{array}$ & $\begin{array}{c}3.47 \%(7) \\
5.45 \%(11)\end{array}$ & $\begin{array}{l}1.98 \%(4) \\
2.97 \%(6)\end{array}$ & $\begin{array}{c}3.47 \%(7) \\
5.45 \%(11)\end{array}$ & $\begin{array}{c}7.92 \%(16) \\
12.87 \%(26)\end{array}$ & $\begin{array}{l}2.97 \% \text { (6) } \\
4.46 \%(9)\end{array}$ \\
\hline $\begin{array}{l}3 \mathrm{CXI} \\
(121) \\
\end{array}$ & $\begin{array}{l}4.96 \%(6) \\
7.44 \%(9)\end{array}$ & $\begin{array}{l}.13 \%(5) \\
4.96 \%(6) \\
\end{array}$ & $\begin{array}{c}98.35 \%(119) \\
99.17 \%(120) \\
\end{array}$ & $\begin{array}{l}95.04 \%(115) \\
95.87 \%(116)\end{array}$ & $\begin{array}{l}50.41 \%(61) \\
71.07 \%(86) \\
\end{array}$ & $\begin{array}{l}47.93 \%(58) \\
62.81 \%(76) \\
\end{array}$ & $\begin{array}{l}4.96 \%(6) \\
7.44 \%(9)\end{array}$ & $100 \%$ & $\begin{array}{l}98.35 \%(119) \\
99.17 \%(120)\end{array}$ & $\begin{array}{l}14.05 \%(17) \\
21.49 \%(26) \\
\end{array}$ & $\begin{array}{l}19.83 \%(24) \\
34.71 \%(42) \\
\end{array}$ & $\begin{array}{l}59.50 \%(72) \\
70.25 \%(85) \\
\end{array}$ & $\begin{array}{r}5.79 \%(7) \\
9.09 \%(11)\end{array}$ & $\begin{array}{l}85.95 \%(104) \\
89.26 \%(108) \\
\end{array}$ & $\begin{array}{c}99.17 \%(120) \\
100 \%(122) \\
\end{array}$ \\
\hline $\begin{array}{l}3 C Y L \\
(121)\end{array}$ & $\begin{array}{l}4.13 \%(5) \\
5.79 \%(7)\end{array}$ & $\begin{array}{c}10.74 \%(13) \\
14.05 \% \\
(17 \mathrm{t})\end{array}$ & $\begin{array}{l}99.17 \%(120) \\
99.17 \%(120)\end{array}$ & $\begin{array}{l}93.39 \%(113) \\
95.04 \%(115)\end{array}$ & $\begin{array}{l}48.76 \%(59) \\
70.25 \%(85)\end{array}$ & $\begin{array}{l}48.76 \%(59) \\
62.81 \%(76)\end{array}$ & $\begin{array}{l}4.96 \%(6) \\
7.44 \%(9)\end{array}$ & $\begin{array}{l}98.35 \%(119) \\
99.17 \%(120)\end{array}$ & $100 \%$ & $\begin{array}{l}14.05 \%(17) \\
21.49 \%(26)\end{array}$ & $\begin{array}{l}19.83 \%(24) \\
35.54 \%(43)\end{array}$ & $\begin{array}{l}59.50 \%(72) \\
70.25 \%(85)\end{array}$ & $\begin{array}{l}5.79 \%(7) \\
9.09 \%(11)\end{array}$ & $\begin{array}{l}87.60 \%(106) \\
90.08 \%(109)\end{array}$ & $\begin{array}{l}99.17 \%(120) \\
99.17 \%(120)\end{array}$ \\
\hline $\begin{array}{l}\text { 3DSL } \\
(479)\end{array}$ & & $\begin{array}{c}2.15 \%(9) \\
4.30 \%(18)\end{array}$ & & & & & $\begin{array}{l}25.30 \%(106) \\
32.70 \%(137)\end{array}$ & & & $100 \%$ & $\begin{array}{l}2.39 \%(10) \\
3.34 \%(14)\end{array}$ & & & & $\begin{array}{l}4.06 \%(17) \\
6.21 \%(26)\end{array}$ \\
\hline $4 \mathrm{E} 0 \mathrm{~V}$ & & & & & & & & & & & & & & & \\
\hline$(49)$ & & & & & & & & & & & & & & & \\
\hline $\begin{array}{l}5 \mathrm{TV} \\
(122\end{array}$ & & & & & & & & & & & $\begin{array}{l}13.11 \%(16) \\
22.95 \%(28)\end{array}$ & $100 \%$ & & & $\begin{array}{l}(72) \\
(85)\end{array}$ \\
\hline $5 \mathrm{TS}$ & $\frac{8.2}{3.9}$ & & & & & & & & & & $97.93 \%$ & $3.31^{\circ}$ & & & $\begin{array}{c}1.45 \%(7) \\
1.47\end{array}$ \\
\hline$(484$ & & & & & & & & & & & & & $100 \%$ & $4.34 \%(21)$ & \\
\hline $6 \mathrm{CE} 2$ & & & & & & & & & & & & & & & \\
\hline$(12$ & & & & & & & & & & & & & & & $89.26 \%(108)$ \\
\hline 6DIK & $\begin{array}{l}4.96 \%(6) \\
7.44 \%(9)\end{array}$ & 4. & & $\begin{array}{l}.21 \%(114) \\
87 \%(116)\end{array}$ & $\begin{array}{l}49.59 \%(60) \\
71.07 \%(86)\end{array}$ & & $\begin{array}{l}4.96 \%(6) \\
7.44 \%(9)\end{array}$ & $99.17 \%(120)$ & & & & & & $\begin{array}{l}86.78 \%(105) \\
89.26 \%(108)\end{array}$ & $100 \%$ \\
\hline & & & & & & & & & $99.17 \%(120)$ & & & $70.25 \%(85)$ & $9.09 \%(11)$ & & \\
\hline
\end{tabular}




\section{References}

1. Thirupathi, K.; Kumar, S.S.; Raju, V.S.; Ravikumar, B.; Krishna, D.R.; Mohan, G.K. A review of medicinal plants of the genus Cordia: Their chemistry and pharmacological uses. J. Nat. Remedies 2008, 8, 1-10.

2. Matias, E.F.F.; Alves, E.F.; do Nascimento Silva, M.K.; de Alencar Carvalho, V.R.; Coutinh, H.D.M.; da Costa, J.G.M. The genus Cordia: Botanists, ethno, chemical and pharmacological aspects. Brazilian J. Pharmacogn. 2015, 25, 542-552. [CrossRef]

3. Moir, M.; Thomson, R.H.; Hausen, B.M.; Simatupang, M.H. Cordiachromes: A new group of terpenoid quinones from Cordia spp. J. Chem. Soc. Chem. Commun. 1972, 6, 363-364. [CrossRef]

4. Moir, M.; Thomson, R.H. Naturally occurring quinones. Part XXII. Terpenoid quinones in Cordia spp. J. Chem. Soc. Perkin Trans. 1 1973, 1352-1357. [CrossRef]

5. Kaur, S.; Singh, V.; Kumar, G.; Kad, G.L.; Singh, J. A short and facile synthesis of 2-(1Z)-(3-hydroxy-3,7-dimethylocta-1,6-dienyl)-1,4-benzenediol and 1-(3'-methoxypropanoyl)-2,4,5trimethoxybenzene isolated from Cordia alliodora. Nat. Prod. Res. 2010, 24, 440-447. [CrossRef]

6. Sinha, A.K.; Joshi, B.P.; Sharma, A.; Kumar, J.K.; Kaul, V.K. Microwave-assisted rapid synthesis of methyl 2,4,5-trimethoxyphenylpropionate, a metabolite of Cordia alliodora. Nat. Prod. Res. 2003, 17, 419-422. [CrossRef]

7. Stevens, K.L.; Jurd, L.; Manners, G. Alliodorin, a phenolic terpenoid from Cordia alliodora. Tetrahedron Lett. 1973, 14, 2955-2958. [CrossRef]

8. Chen, T.K.; Ales, D.C.; Baenziger, N.C.; Wiemer, D.F. Ant-Repellent Triterpenoids from Cordia alliodora. J. Org. Chem. 1983, 48, 3525-3531. [CrossRef]

9. Kahn, P.H.; Cossy, J. A short synthesis of cordiachromene. Tetrahedron Lett. 1999, 40, 8113-8114. [CrossRef]

10. Bouzbouz, S.; Goujon, J.-Y.; Deplanne, J.; Kirschleger, B. Enantioselective Synthesis of Cordiachromene. Eur. J. Org. Chem. 2000, 2000, 3223-3228. [CrossRef]

11. Gary Manners, B.D.; Jurd, L.; Southwell, C.K.; Bultman, J.D.; Moir, M.; Thomson, R.H.; Perkin, J. The Hydroquinone Terpenoids of Cordia alliodora. J. Chem. Soc. Perkin Trans. 1976, 1, 405-410. [CrossRef]

12. Ioset, J.R.; Marston, A.; Gupta, M.P.; Hostettmann, K. Antifungal and larvicidal compounds from the root bark of Cordia alliodora. J. Nat. Prod. 2000, 63, 424-426. [CrossRef]

13. Fouseki, M.M.; Damianakos, H.; Karikas, G.A.; Roussakis, C.; Gupta, M.P.; Chinou, I. Chemical constituents from Cordia alliodora and C. colloccoca (Boraginaceae) and their biological activities. Fitoterapia 2016, 15, 9-14. [CrossRef]

14. Matias, E.F.F.; Alves, E.F.; Silva, M.K.N.; Carvalho, V.R.A.; Figueredo, F.G.; Ferreira, J.V.A.; Coutinho, H.D.M.; Silva, J.M.F.L.; Ribeiro-Filho, J.; Costa, J.G.M. Seasonal variation, chemical composition and biological activity of the essential oil of Cordia verbenacea DC (Boraginaceae) and the sabinene. Ind. Crops Prod. 2016, 87, 45-53. [CrossRef]

15. De Alencar Carvalho, V.R.; do Nascimento Silva, M.K.; Aguiar, J.J.S.; de Carvalho Nilo Bitu, V.; da Costa, J.G.M.; Ribeiro-Filho, J.; Coutinho, H.D.M.; Pinho, A.I.; Fagner Ferreira Matias, E. Antibiotic-Modifying Activity and Chemical Profile of the Essential Oil from the Leaves of Cordia verbenacea DC. J. Essent. Oil Bear. Plants 2017, 20. [CrossRef]

16. Matias, E.F.F.; Alves, E.F.; Silva, M.K.N.; Carvalho, V.R.A.; Medeiros, C.R.; Santos, F.A.V.; Bitu, V.C.N.; Souza, C.E.S.; Figueredo, F.G.; Boligon, A.A.; et al. Potentiation of antibiotic activity of aminoglycosides by natural products from Cordia verbenacea DC. Microb. Pathog. 2016, 95, 111-116. [CrossRef]

17. Costa De Oliveira, D.M.; Luchini, A.C.; Seito, L.N.; Gomes, J.C.; Crespo-López, M.E.; Di Stasi, L.C. Cordia verbenacea and secretion of mast cells in different animal species. J. Ethnopharmacol. 2011, 135, 463-468. [CrossRef]

18. Parisotto, E.B.; Michielin, E.M.Z.; Biscaro, F.; Ferreira, S.R.S.; Filho, D.W.; Pedrosa, R.C. The antitumor activity of extracts from Cordia verbenacea D.C. obtained by supercritical fluid extraction. J. Supercrit. Fluids 2012. [CrossRef]

19. Ticli, F.K.; Hage, L.I.S.; Cambraia, R.S.; Pereira, P.S.; Magro, Â.J.; Fontes, M.R.M.; Stábeli, R.G.; Giglio, J.R.; França, S.C.; Soares, A.M.; et al. Rosmarinic acid, a new snake venom phospholipase A2 inhibitor from Cordia verbenacea (Boraginaceae): Antiserum action potentiation and molecular interaction. Toxicon 2005, 46, 318-327. [CrossRef] 
20. Missouri Botanical Garden Tropicos Database. 2018. Available online: http://tropicos.org (accessed on 20 September 2019).

21. Luzuriaga-Quichimbo, C.X. Estudio Etnobotánico en Comunidades Kichwas Amazónicas de Pastaza, Ecuador. Doctoral Thesis, Universidad de Extremadura, Badajoz, España, 2017. Available online: http: //dehesa.unex.es/handle/10662/6419 (accessed on 10 September 2018).

22. Dos Santos, R.F.E.P.; Silva Silva, I.S.D.M.; d'Costa, L.R.; Mendonça Barbosa, A.; Santos Silva, K.; Ribeiro Amorim, M.; Mendonça Diz, F.; Honório Lins, T.; Santos Sales Verissimo, R.C.; Ferreira Padilha, F.; et al. Study of antimicrobial potential and cytotoxic of Cordia nodosa species. BMC Proc. 2014, 8, P69. [CrossRef]

23. De La Torre, L.; Navarrete, H.; Muriel, M.P.; Macía, M.J.; Balslev, H. Enciclopedia de las Plantas Útiles del Ecuador; Herbario QCA de la Escuela de Ciencias Biológicas de la Pontificia Universidad Católica del Ecuador \& Herbario AAU del Departamento de Ciencias Biológicas de la Universidad de Aarhus: Aarhus, Denmark, 2008; ISBN 978-9978-77-135-8.

24. OMS Organización Mundial de la Salud Datos y Cifras Situación Mundial Desafíos a la Producción de Antídotos. Available online: https://www.who.int/es/news-room/fact-sheets/detail/snakebite-envenoming (accessed on 10 September 2019).

25. Convention on Biological Diversity. 2010 CoP10 Decisions. 2010; pp. 1-7. Available online: https: //www.cbd.int/decisions/cop/?m=cop-10 (accessed on 10 September 2019).

26. De Filipps, R.; Maina, S.L.; Crepin, J. Medicinal plants of the Guianas (Guyana, Surinam, French Guiana); Department of Botany, National Museum of Natural History, Smithsonian Institution: Washington, DC, USA, 2004.

27. Valadeau, C.; Castillo, J.A.; Sauvain, M.; Lores, A.F.; Bourdy, G. The rainbow hurts my skin: Medicinal concepts and plants uses among the Yanesha (Amuesha), an Amazonian Peruvian ethnic group. J. Ethnopharmacol. 2010, 127, 175-192. [CrossRef]

28. Guimaraes, C.; Moreira-Dill, L.; Fernandes, R.; Costa, T.; Hage-Melim, L.; Marcussi, S.; Carvalho, B.; Silva, S.; Zuliani, J.; Fernandes, C.; et al. Biodiversity as a Source of Bioactive Compounds Against Snakebites. Curr. Med. Chem. 2014. [CrossRef] [PubMed]

29. Salvador, G.H.; Dos Santos, J.I.; Lomonte, B.; Fontes, M.R. Crystal structure of a phospholipase A2 from Bothrops asper venom: Insights into a new putative "myotoxic cluster". Biochimie 2017, 133, 95-102. [CrossRef] [PubMed]

30. Feliciano, P.R.; Rustiguel, J.K.; Soares, R.O.; Sampaio, S.V.; Cristina Nonato, M. Crystal structure and molecular dynamics studies of L-amino acid oxidase from Bothrops atrox. Toxicon 2017, 128, 50-59. [CrossRef] [PubMed]

31. dos Santos, J.I.; Soares, A.M.; Fontes, M.R. Comparative structural studies on Lys49-phospholipases A(2) from Bothrops genus reveal their myotoxic site. J. Struct. Biol. 2009, 167, 106-116. [CrossRef] [PubMed]

32. Salvador, G.H.M.; Dreyer, T.R.; Gomes, A.A.S.; Cavalcante, W.L.G.; Dos Santos, J.I.; Gandin, C.A.; de Oliveira Neto, M.; Gallacci, M.; Fontes, M.R.M. Structural and functional characterization of suramin-bound MjTX-I from Bothrops moojeni suggests a particular myotoxic mechanism. Sci. Rep. 2018, 8, 10317. [CrossRef]

33. Cardoso, F.F.; Borges, R.J.; Dreyer, T.R.; Salvador, G.H.M.; Cavalcante, W.L.G.; Pai, M.D.; Gallacci, M.; Fontes, M.R.M. Structural basis of phospholipase A2-like myotoxin inhibition by chicoric acid, a novel potent inhibitor of ophidian toxins. Biochim. Biophys. Acta Gen. Subj. 2018, 1862, 2728-2737. [CrossRef]

34. Watanabe, L.; Soares, A.M.; Ward, R.J.; Fontes, M.R.; Arni, R.K. Structural insights for fatty acid binding in a Lys49-phospholipase A (2): Crystal structure of myotoxin II from Bothrops moojeni complexed with stearic acid. Biochimie 2005, 87, 161-167. [CrossRef]

35. Ullah, A.; Souza, T.A.; Abrego, J.R.; Betzel, C.; Murakami, M.T.; Arni, R.K. Structural insights into selectivity and cofactor binding in snake venom L-amino acid oxidases. Biochem. Biophys. Res. Commun. 2012, 421, 124-128. [CrossRef]

36. Magro, A.J.; Takeda, A.A.; Soares, A.M.; Fontes, M.R. Structure of BthA-I complexed with p-bromophenacyl bromide: Possible correlations with lack of pharmacological activity. Acta Crystallogr. Sect. D 2005, 61, 1670-1677. [CrossRef] 
37. Marchi-Salvador, D.P.; Correa, L.C.; Magro, A.J.; Oliveira, C.Z.; Soares, A.M.; Fontes, M.R. Insights into the role of oligomeric state on the biological activities of crotoxin: Crystal structure of a tetrameric phospholipase A2 formed by two isoforms of crotoxin B from Crotalus durissus terrificus venom. Proteins 2008, 72, 883-891. [CrossRef]

38. Lee, W.H.; Da Silva Giotto, M.T.; Marangoni, S.; Toyama, M.H.; Polikarpov, I.; Garratt, R.C. Structural Basis for Low Catalytic Activity in Lys49 Phospholipases A2-A Hypothesis: The Crystal Structure of Piratoxin II Complexed to Fatty Acid. Biochemistry 2001, 40, 28. [CrossRef] [PubMed]

39. Muniz, J.R.; Ambrosio, A.L.; Selistre-de-Araujo, H.S.; Cominetti, M.R.; Moura-da-Silva, A.M.; Oliva, G.; Garratt, R.C.; Souza, D.H. The three-dimensional structure of bothropasin, the main hemorrhagic factor from Bothrops jararaca venom: Insights for a new classification of snake venom metalloprotease subgroups. Toxicon 2008, 52, 807-816. [CrossRef] [PubMed]

40. Lingott, T.J.; Schleberger, C.; Gutierrez, J.M.; Merfort, I. High-Resolution Crystal Structure of the Snake Venom Metalloproteinase Bap1 Complexed with a Peptidomimetic: Insight Into Inhibitor Binding. Biochemistry 2009, 48, 6166. [CrossRef] [PubMed]

41. Kumar, J.V.; Chien, K.Y.; Lin, C.C.; Chiang, L.C.; Lin, T.H.; Wu, W.G. Crystal Structure of L-Amino Acid Oxidase from Naja Atra (Taiwan Cobra). Available online: https://www.rcsb.org/structure/5Z2G (accessed on 13 November 2019).

42. Gergiova, D.; Murakami, M.T.; Perbandt, M.; Arni, R.K.; Betzel, C. Structure of Native L-amino Acid Oxidase from Vipera ammodytes Ammodytes: Stabilization of the Quaternary Structure by Divalent Ions and Structural Changes in the Dynamic Active Site. Available online: https://www.rcsb.org/structure/3KVE (accessed on 13 November 2019).

43. Lin, C.C.; Wu, B.S.; Wu, W.G. Crystal Structure of Snake Venom Phosphodiesterase (PDE) from Taiwan Cobra (Naja atra atra). Available online: http://dx.doi.org/10.2210/PDB5GZ4/PDB (accessed on 13 November 2019).

44. Trabi, M.; Millers, E.-K.; Richards, R.; Snelling, H.; Keegan, R.; Lavin, M.F.; de Jersey, J.; Guddat, L.W.; Masci, P. Mechanistic Studies on the Anticoagulant Activity of a Phospholipase A2 from the Venom of the Australian King Brown Snake (Pseudechis australis). Available online: https://www.rcsb.org/structure/3V9M (accessed on 13 November 2019).

45. Fremont, D.H.; Anderson, D.H.; Wilson, I.A.; Dennis, E.A.; Xuong, N.H. Crystal structure of phospholipase A2 from Indian cobra reveals a trimeric association. Proc. Natl. Acad. Sci. USA 1993, 90, 342-346. [CrossRef]

46. Zhang, H.; Teng, M.; Niu, L.; Wang, Y.; Wang, Y.; Liu, Q.; Huang, Q.; Hao, Q.; Dong, Y.; Liu, P. Purification, partial characterization, crystallization and structural determination of AHP-LAAO, a novel L-amino-acid oxidase with cell apoptosis-inducing activity from Agkistrodon halys pallas venom. Acta Crystallogr. Sect. D Biol. Crystallogr. 2004, 60, 974-977. [CrossRef]

47. Lin, C.C.; Wu, B.S.; Wu, W.G. Crystal Structure of Snake Venom Phosphodiesterase (PDE) from Taiwan Cobra (Naja atra atra) in Complex with AMP. Available online: https://www.rcsb.org/structure/5GZ5 (accessed on 13 November 2019).

48. Segelke, B.W.; Nguyen, D.; Chee, R.; Xuong, N.H.; Dennis, E.A. Structures of two novel crystal forms of Naja naja naja phospholipase A2 lacking Ca2+ reveal trimeric packing. J. Mol. Biol. 1998, 279, $223-232$. [CrossRef]

49. Mendes, M.M.; Vieira, S.A.P.B.; Gomes, M.S.R.; Paula, V.F.; Alcântara, T.M.; Homsi-Brandeburgo, M.I.; Dos Santos, J.I.; Magro, A.J.; Fontes, M.R.M.; Rodrigues, V.M. Triacontyl p-coumarate: An inhibitor of snake venom metalloproteinases. Phytochemistry 2013. [CrossRef] [PubMed]

50. Laskowski, R.A.; Swindells, M.B. LigPlot+: Multiple ligand-protein interaction diagrams for drug discovery. J. Chem. Inf. Model. 2011. [CrossRef] [PubMed]

51. Alcaraz, M.J.; Hoult, J.R. Effects of hypolaetin-8-glucoside and related flavonoids on soybean lipoxygenase and snake venom phospholipase A2. Arch. Int. Pharmacodyn. Ther. 1985, 278, 4-12. [PubMed]

52. Girish, K.S.; Kemparaju, K. Inhibition of Naja naja venom hyaluronidase: Role in the management of poisonous bite. Life Sci. 2006, 78, 1433-1440. [CrossRef]

53. Nishijima, C.M.; Rodrigues, C.M.; Silva, M.A.; Lopes-Ferreira, M.; Vilegas, W.; Hiruma-Lima, C.A. Anti-hemorrhagic activity of four brazilian vegetable species against Bothrops jararaca venom. Molecules 2009, 14, 172-180. [CrossRef]

54. Moher, D.; Liberati, A.; Tetzlaff, J.; Altman, D.G.; PRISMA Group. Preferred reporting items for systematic reviews and meta-analyses: The PRISMA statement. Int. J. Surg. 2010. [CrossRef] 
55. Tu, M.; Cheng, S.; Lu, W.; Du, M. Advancement and prospects of bioinformatics analysis for studying bioactive peptides from food-derived protein: Sequence, structure, and functions. TrACTrends Anal. Chem. 2018. [CrossRef]

56. Tu, M.; Wang, C.; Chen, C.; Zhang, R.; Liu, H.; Lu, W.; Jiang, L.; Du, M. Identification of a novel ACE-inhibitory peptide from casein and evaluation of the inhibitory mechanisms. Food Chem. 2018. [CrossRef]

(C) 2019 by the authors. Licensee MDPI, Basel, Switzerland. This article is an open access article distributed under the terms and conditions of the Creative Commons Attribution (CC BY) license (http://creativecommons.org/licenses/by/4.0/). 